\title{
PENGEMBANGAN PANDUAN PRAKTIKUM BERBASIS INKUIRI TERBIMBING PADA MATERI FLUIDA STATIS
}

\author{
I Dewa Putu Nyeneng ${ }^{1}$, Nengah Maharta ${ }^{2}$, Nurul Kartika ${ }^{3}$ \\ ${ }^{1,2,3}$ Pendidikan Fisika, FKIP, Universitas Lampung
}

\begin{abstract}
Abstrak
Penelitian ini bertujuan untuk mendeskripsikan validitas, serta kemenarikan, kemudahan, dan kemanfaatan produk. Produk yang dikembangkan berupa panduan praktikum berbasis inkuiri terbimbing pada materi fluida statis untuk meningkatkan keterampilan proses sains. Penelitian ini dilakukan di MAN 1 Lampung Timur dengan menggunakan metode penelitian Research and Development $(R \& D)$. Pengembangan dilakukan dengan mengadaptasi dari model penelitian dan pengembangan Borg and Gall yaitu, pengumpulan data, perencanaan, pengembangan produk, validasi produk, revisi produk, dan uji coba produk. Pengumpulan data menggunakan teknik wawancara dan teknik angket. Data hasil wawancara dan angket dianalisis kemudian digunakan untuk merencanakan produk. Produk yang telah dikembangkan dinilai tingkat validitas desain dan materi oleh dua orang dosen pendidikan fisika Universitas Lampung dan satu orang guru fisika MAN 1 Lampung Timur. Nilai Validitas desain mendapat nilai rata-rata 3,57 dengan kualitas sangat layak dan validitas materi mendapat nilai rata-rata 3,33 dengan kualitas layak. Setelah melalui uji validasi, produk direvisi sesuai saran dan perbaikan, kemudian produk diuji kemenarikan, kemudahan, dan kemanfaatan kepada 4 orang siswa-siswi kelas XI MIA 2 MAN 1 Lampung Timur yang diambil secara acak. Hasil uji kemenarikan mendapat nilai rata-rata 3,29 dengan kualitas tinggi, uji kemudahan mendapat nilai rata-rata 3,28 dengan kualitas tinggi, dan uji kemanfaatan mendapat nilai rata-rata 3,29 dengan kualitas tinggi.
\end{abstract}

Kata kunci: Panduan praktikum, fluida statis, inkuiri terbimbing 


\begin{abstract}
This study aims to describe the validity, as well as the attractiveness, convenience, and usefulness of the product. The product developed was a guided inquiry-based practicum guide on static fluid material to improve science process skills. This research was conducted at MAN 1 Lampung Timur using the Research and Development (R\&D) research method. Development is carried out by adapting the Borg and Gall research and development model, namely, data collection, planning, product development, product validation, product revisions, and product trials. Data collection using interview techniques and questionnaire techniques. Data from interviews and questionnaires were analyzed and then used to plan products. The products that have been developed are assessed the level of design and material validity by two physics education lecturers from Lampung University and one physics teacher at MAN 1 Lampung Timur. Value of Design validity gets an average value of 3.57 with very decent quality and material validity gets an average value of 3.33 with decent quality. After going through the validation test, the product is revised according to suggestions and improvements, then the product is tested for its attractiveness, convenience, and usefulness to 4 students of class XI MIA 2 MAN 1 East Lampung randomly. The results of the attractiveness test got an average value of 3.29 with high quality, the ease of testing got an average value of 3.28 with high quality, and the benefit test got an average value of 3.29 with high quality.
\end{abstract}

Keywords: Practicum guide, static fluid, guided inquiry

\title{
PENDAHULUAN
}

Kompetensi yang diperlukan dalam menghadapi tantangan era ke 21 salah satunya adalah kemampulan berpikir kritis. Kemampuan berpikir kritis sangat diperlukan untuk mempersiapkan generasi muda agar mampu membawa bangsa menjadi lebih maju (Saheri et al., 2017). Masalah yang seringkali dijumpai adalah rendahnya kemampuan berpikir kritis peserta didik (Kurniastuti et al., 2016 dan Wijaya et al., 2018). Berdasarkan observasi, kajian data, dan wawancara pada tahun 2018 bahwa masih banyak peserta didik mengalami kendala dalam memahami konsep kimia salah satunya adalah materi redoks. Nilai rata-rata hasil UAS materi kimia kelas X-MIA 1 SMAN 10 Semarang Tahun ajaran 2018/2019 dapat dilihat pada Tabel 1. 
Tabel 1 Nilai rata-rata hasil UAS kimia kelas X-MIA 1

\begin{tabular}{ccc}
\hline No. & Kelas & Rata-rata nilai \\
\hline 1 & X-MIA 1 & 46,8 \\
2 & X-MIA 2 & 57,2 \\
3 & X-MIA 3 & 42,5 \\
4 & X-MIA 4 & 67,7 \\
\hline
\end{tabular}

Tabel 1 menunjukkan bahwa rata-rata pencapaian hasil UAS kimia adalah sebesar 56,48. Rendahnya rata-rata nilai UAS disebabkan karena beberapa faktor, diantaranya adalah rendahnya pemahaman peserta didik terhadap materi kimia, rendahnya kemampuan berpikir kritis peserta didik serta proses pembelajaran belum menerapkan student center. Peserta didik tidak diajak untuk memecahkan permasalahan dalam diskusi kelas yang dapat merangsang timbulnya ide baru dari hasil pemikiran anggota kelompok pada saat diskusi yang berlangsung (Laliyo, 2012). Solusi yang dapat adalah dengan melakukan inovasi pembelajaran.

Inovasi yang dapat dilakukan guru ialah inovasi model Problem Based Learning yang dibantu dengan Lembar Kerja Peserta Didik (LKPD) bermuatan etnosains yang akan digunakan saat proses belajar kimia. Harapan diterapkannya model dengan inovasi ini adalah dapat mengembangkan kemampuan berpikir kritis peserta didik. Penerapan student center learning diyakini dapat mengembangkan kemampuan berpikir kritis (Aziz et al., 2014). Penelitian yang dilakukan oleh Shaer dan Gaber (2014) menunjukkan bahwa penggunaan model $P B L$ dapat meningkatkan kemampuan berpikir kritis peserta didik.

PBL diharapkan mampu menyediakan ruang kepada peserta didik untuk mengeksplorasi sumber belajar lebih luas lagi. Implementasi PBL dalam pembelajaran dengan mengkaitkan dengan budaya (etnosains) yang ada merupakan langkah yang tepat. Etnosains merupakan suatu pendekatan dalam pembelajaran yang mengaitkan materi pembelajaran dengan budaya yang ada di lingkungan sekitar. Etnosains adalah pengetahuan asli dalam bentuk bahasa, adat istiadat dan budaya, moral; sebagai serta teknologi yang diciptakan oleh masyarakat atau orang tertentu yang mengandung pengetahuan ilmiah.

Etnosains pada penelitian ini mencakup tentang peristiwa perkaratan besi, pembuatan tape dan proses pemasakan. Rumusan masalah pada penelitian ini adalah bagaimana kemampuan berpikir kritis peserta didik setelah diterapkannya model $P B L$ 
yang berbantuan LKPD bermuatan etnosains. Penelitian ini bertujuan untuk mengetahui kemampuan berpikir kritis peserta didik setelah penerapan $P B L$ berbantuan LKPD bermuatan etnosains pada materi reaksi redoks.

\section{METODE PENELITIAN}

Penelitian ini adalah penelitian studi kasus dengan desain single holistic. Penelitian diakukan di SMAN 10 Semarang di kelas X-MIA 1 dipilih secara purposive sampling yang terdiri dari 36 peserta didik. Teknik pengumpulan data penelitian meliputi tes kemampuan berpikir kritis, observasi dan angket tanggapan yang telah dinyatakan valid oleh pakar. Kemampuan berpikir kritis diukur melalui 2 penilaian yaitu tes dan nontes. Soal tes berupa soal uraian sebanyak 10 pertanyaan digunakan untuk mengetahui kemampuan berpikir kritis pada bagian pengetahuan. Penilaian nontes berupa lembar observasi yang berisi 7 aspek diukur untuk mengetahui kemampuan berpikir kritis pada bagian keterampilan. Reliabilitas lembar observasi dan angket dihitung menggunakan rumus Cronbach Alfa, dan masing-masing diperoleh koefisien sebesar 0,72 dan 0,86 .

Dasar pengukuran yang digunakan untuk mengetahui kemampuan berpikir kritis merupakan adaptasi indikator dari Ennis yang dimodifikasi sedemikian rupa sesuai dengan kebutuhan model pembelajaran yang digunakan. Indikator yang digunakan pada penelitian berjumlah 12 indikator yang dibagi menjadi 2 kelompok. 5 indikator diukur pada bagian pengetahuan dan 7 indikator diukur pada bagian keterampilan. Rentang skor penilaian dari 1 sampai 4. Kriteria penskoran yang disusun mengacu pada skor aspek yang telah ditetapkan. Skor 1 menggambarkan nilai terendah suatu aspek, sebaliknya skor 4 menggambarkan tingginya nilai suatu aspek. Pada bagian ini menjelaskan bagaimana penelitian itu dilakukan.

\section{HASIL DAN PEMBAHASAN}

Hasil penelitian berupa skor kemampuan berpikir kritis dan respon peserta didik terhadap penerapan pembelajaran kimia yang digunakan. Pembelajaran berbasis masalah dilaksanakan selama 6 pertemuan. Kegiatan pembelajaran terbagi menjadi 3 bagian, yaitu pembuka, inti dan penutup. Pembelajaran diawali dari menghadirkan isuisu aktual yang tidak asing bagi peserta didik. Kegiatan inti berisi kegiatan 
pembelajaran yang disesuaikan dengan sintak $P B L$ yang diawali dengan orientasi peseta didik terhadap masalah kemudian disusul fase pengorganisasian peserta didik untuk belajar. Pengorganisasikan peserta didik untuk belajar dengan membentuk 6 kelompok yang masing-masing terdiri dari 6 peserta didik.

Diskusi membahas permasalahan yang terdapat pada masalah kehidupan seharihari dan berhubungan dengan etnosains. Setiap kelompok diberi LKPD bermuatan etnosains yang berisi sintak $P B L$ mendiskusikan permasalahan yang disajikan. Kegiatan diskusi merangsang peserta didik menjadi lebih aktif dalam pembelajaran. Terlebih permasalahan yang disajikan sering dijumpai dalam kehidupan sehari-hari. Kegiatan pembelajaran diakhiri dengan review materi yang telah dibahas selama proses pembelajaran berlangsung. Hasil analisis ketercapaian kemampuan berpikir kritis peserta didik dapat dilihat pada Tabel 2.

Tabel 2 tampak bahwa pencapaian persentase berpikir kritis peserta didik tertinggi pada kriteria 66,67\%. Hal ini menunjukkan bahwa penggunaan model PBL yang dibantu LKPD bermuatan etnosains dapat digunakan untuk mengembangkan kemampuan berpikir kritis. Sejalan dengan hasil penelitian (Luzyawati (2017) bahwa peningkatan kemampuan berpikir kritis yang dialami oleh peserta didik, disebabkan karena keaktifan peserta didik dalam mencari informasi untuk menyelesaikan masalah yang disajikan. Persentase pencapaian masing-masing indikator kemampuan berpikir kritis dapat dilihat pada Tabel 3.

Tabel 2. Hasil analisis kemampuan berpikir kritis peserta didik secara umum

\begin{tabular}{ccc}
\hline Kriteria & Peserta didik & Persentase $(\%)$ \\
\hline SB & 1 & 2,78 \\
B & 23 & 63,89 \\
C & 10 & 27,78 \\
TB & 2 & 5,56 \\
STB & 0 & 0 \\
\hline
\end{tabular}

Keterangan:

$\begin{array}{llll}\text { SB } & =\text { Sangat Baik, } & \text { B } & =\text { Baik } \\ \text { C } & =\text { Cukup } & \text { TB }=\text { Tidak Baik } \\ \text { STB } & =\text { Sangat Tidak Baik } & & \end{array}$


Tabel 3 Persentase pencapaian kemampuan berpikir kritis perindikator

\begin{tabular}{clc}
\hline No. & \multicolumn{1}{c}{ Indikator Keterampilan } & Persentase $(\%)$ \\
\hline 1. & Mencari pernyataan yang jelas dari pertanyaan & 75,69 \\
2. & Mencari alasan & 66,67 \\
3. & Mengetahui informasi dengan baik & 56,25 \\
4. & Bersikap dan berpikir terbuka & 52,43 \\
5. & Mencari alternatif & 83,68 \\
6. & Bertanya dan menjawab pertanyaan & 66,67 \\
7. & Memakai sumber & 67,36 \\
8. & Observasi dan mempertimbangkan hasil observasi & 75,69 \\
9. & Membuat deduksi dan mempertimbangkan hasil & 54,17 \\
& induksi & \\
10. Membuat induksi dan mempertimbangkan hasil & 44,44 \\
11. & Menentukan tindakan & 47,92 \\
12. & Berinteraksi dengan orang lain & 86,81 \\
\hline
\end{tabular}

Pada Tabel 3 menunjukkan bahwa indikator yang pencapaiannya paling tinggi terdapat pada indikator berinteraksi dengan orang lain. Kegiatan diskusi menuntut peserta didik untuk aktif dalam membahas permasalahan yang disajikan. Keaktifan ini bisa disebabkan karena adanya kerjasama antar anggota kelompok. Peserta didik akan dapat mengembangkan kemampuan berpikir kritis dan terpacu untuk mencari tahu solusi permasalahan secara bersama (collaboration) (Aryanti et al., 2017). Indikator yang tingkat pencapainnya paling rendah terdapat pada indikator membuat induksi dengan persentase yang diperoleh sebesar $44,44 \%$.

Indikator yang pertama adalah indikator mencari pernyataan yang jelas Inidkator ini memperoleh persentase yang baik yaitu sebesar 75,69\%. Proses pemahaman dan pengetahuan yang dimiliki peserta didik cukup baik. Peserta didik mengerjakan soalsesuai dengan argumennya sendiri dan mereka mengerjakan tanpa mengalami kesulitan, sehingga diperoleh rata-rata yang baik. Penelitian ini juga sejalan dengan (Nuryanti et al., 2018) bahwa indikator mencari pernyataan yang jelas memperoleh persentase yang tinggi. Peserta didik mampu menuliskan hal yang mereka ketahui dengan benar yang sesuai dari bacaan yang disajikan. Persentase ini menunjukkan bahwa model $P B L$ berbantuan LKPD bermatan etnosains cocok digunakan u untuk mengukur kemampuan berpikir kritis peserta didik..

Pencapaian persentase yang diperoleh pada indikator kedua adalah sebesar 66,67\% dan dikatakan cukup baik. Peserta didik mampu menjelaskan alasan mengapa 
reaksi yang terjadi pada bacaan 1 maupun 2 termasuk dalam reaksi redoks atau bukan. Perolehan persentase ini disebabkan karena ada peserta didik masih kesulitan dalam menentukan bilangan oksidasi dan konsep reaksi redoks. Hal ini membuat peserta didik sedikit mengalami kesulitan untuk membedakan apakah reaksi redoks. Sepadan dengan penelitian yang dilakukan oleh (Andrianie et al., 2018) juga menyebutkan bahwa masih terdapat peserta didik yang mengalami kesulitan dalam menentukan bilangan oksidasi dan konsep reaksi redoks. Penggunaan pembelajaran yang bermuatan kearifan lokal atau etnosains memungkinkan peserta didik untuk menghubungkan dan mengaitkan konsep-konsep materi redoks dalam kehidupan sehari-hari (Imansari et al., 2018).

Indikator mengetahui informasi dengan baik memperoleh persentase sebesar 56,25\% termasuk ke dalam kategori cukup.Pencapaian persentase ini disebabkan karena peserta didik kesulitan dalam mengingat aturan bilangan oksidasi sehingga berpengaruh terhadap penentuan oksidator, reduktor, zat hasil oksidasi dan zat hasil reduksi. Diskusi yang berlangsung pada saat pembelajaran juga kurang efektif, sementara itu merujuk pada jawaban peserta didik, jawaban yang dituliskan sebagian besar peserta didik dalam menjawab oksidator dan reduktor hanya menyebutkan unsurnya bukan senyawanya. Sehingga diperoleh persentase yang rendah dan perlu adanya refleksi ulang agar peserta didik jauh lebih memahami materi. Penelitian ini juga sejalan dengan penelitian oleh (Nuryanti et al., 2018) menyebutkan bahwa dalam penelitiannya masih terdapat beberapa peserta didik yang sudah mampu membuat definisi sesuai dengan informasi yang diketahui tetapi masih banyak yang belum tepat.

Indikator keempat adalah bersikap dan berpikir terbuka. Sebagian peserta didik menjawab bahwa penghilangan karat tidak bisa meggunakan bahan yang bersifat basa. Mereka berpikir bahwa proses penghilangan karat pada besi hanya bisa dihilangkan dengan bahan yang bersifat asam lemah saja. Peserta didik hanya mengingat bahwa proses penghilangan karat pada besi yang dibahas pada saat diskusi hanya dengan menggunakan air kelapa. Rata-rata persentase ketercapaian pada indikator ini adalah sebesar 52,43\%. Sementara persentase yang diperoleh untuk kelompok tinggi adalah $61,46 \%$ dan kelompok rendah adalah sebesar 45,83\%. Kelompok tinggi termasuk dalam kategori cukup.

Analisis data menunjukkan bahwa persentase pencapaian indikator mencari alternative termasuk dalam kriteria baik yaitu sebesar 83,68\%. Pembelajaran yang 
mengaitkan dengan materi yang ada dalam kehidupan sehari-hari membuat peserta didik lebih memahami materi pelajaran dan mendorong minat belajar peserta didik (Baskoro \& Rosdiana, 2018). Proses diskusi berlangsung dengan baik dan peserta didik memperhatikan materi ditunjukkan dengan banyak peserta didik yang aktif menjawab pertnyaan yang dilntarkan oleh guru. Salah satu pertanyaan yang dilontarkan adalah usaha apa yang diperlukan untuk mencegah terjadinya proses pengaratan pada besi. Responden 2 yang merupakan peserta didik kelompok rendah, ia mampu menyebutkan beberapa cara yang dapat digunakan yaitu di cat dan di beri oli pada saat proses diskusi berlangsung. Proses pecegahan karat besi yang sering sekali dijumpai dalam kehidupan sehari-hari salah satunya adalah di cat dan diberi pelumas. Pembelajaran yang dikaitkan dengan kearifan lokal yang ada dalam masyarakat sekitar menjadikan pembelajaran lebih bermakna bagi peserta didik.

Indikator keenam adalah bertanya dan menjawab pertanyaan.Hasil analisis pencapaian persentase pada indikator bertanya dan menjawab pertanyaan adalah sebesar $66,67 \%$. Pencapaian persentase pada indikator bertanya dan menjawab pertanyaan termasuk dalam kategori cukup. Perolehan pencapaian persentase ini sejalan dengan penelitian yang dilakukan oleh (Fernanda et al., 2019) bahwa adanya kegiatan diskusi membuat peserta didik aktif bertanya dan menjawab pertanyaan.

Indikator ketujuh adalah memakai sumber. Penggunaan model $P B L$ berbantuan LKPD bermuatan etnosains memberikan kesempatan kepada peserta didik untuk melatih dan menerapkan kemampuan dalam mempertimbangkan kredibilitas sumber untuk menjawab permasalahan. Tabel 3 menunjukkan bahwa indikator memakai sumber mencapai persentase sebesar 67,36\%. Mereka mampu mengolah informasi suatu sumber dengan cukup baik, baik sumber yang pernah di dengar maupun dilihat.Peserta didik juga mampu menggunakannya untuk menyelesaikan permasalahan yang ada.

Pencapaian persentase pada indikator mempertimbangkan hasil observasi pada kelompok tinggi dan rendah masing-masing adalah sebesar 80,21\% dan 58,33\%. Hasil pencapaian indikator observasi dan mempertimbangkan hasil observasi diukur dengan menggunakan instrumen lembar observasi. Sebagian besar peserta didik sudah baik dalam mencatat hasil observasi praktikum dan sudah bisa menjawab sebagian dari permasalahan yang disajikan. Sejalan dengan penelitian oleh (Basheer et al., 2016) menyimpulkan bahwa pembelajaran praktikum dapat membuat peserta didik menjadi 
lebih aktif sehingga mempermudah mengingat konsep dan mengolah informasi pembelajaran yang diperoleh.

Kemampuan membuat deduksi dan mempertimbangkan hasil deduksi merupakan kemampuan peserta didik dalam menafsirkan data.Peserta didik menganalisis hasil data yang diperoleh pada saat melakukan praktikum pencampuran logam ke dalam larutan $\mathrm{HCl} 1 \mathrm{M}$. Hasil penelitian menunjukkan bahwa indikator membuat deduksi dan mempertimbangkan hasil deduksi diperoleh persentase sebesar $54,17 \%$. Hal ini menunjukkan bahwa tidak semua peserta didik kelompok tinggi memiliki kemampuan menafsirkan data dengan baik.Persentase ini disebabkan karena banyak peserta didik yang melakukan kesalahan pada saat praktikum seperti tidak menutup tabung reaksi setelah pemasukkan logam.Kesalahan lainnya adalah ketika mulut tabung dibuka ada beberapa kelompok yang tidak langsung menguji adanya gas hidrogen.

Hasil analisis memperoleh data pencapaian indikator membuat induksi dan mempertimbangkan hasil induksi didapatkan persentase yang paling rendah yaitu sebesar $44,44 \%$. Rata-rata peserta didik dalam menarik kesimpulan yang dituliskan pada laporan hanya menyebutkan bahwa percobaan yang dilakukan merupakan reaksi redoks dan tidak menjelaskan hubungannya degan pembuatan gas hidrogen. Sejalan dengan penelitian (Saputra et al., 2016) bahwa pencapaian indikator membuat induksi dan mempertimbangkan hasil induksi diperoleh pencapaian yang rendah. Hal inidisebaban karena peserta didik belum terbiasa untuk memberikan hipotesis dan simpulan. Persentase yang didapatkan oleh peserta didik kelompok atas maupun rendah memiliki persentase yang sama rendahnya. Secara berturut-turut adalah 54,91\% dan 33,33\%. Hasil analisis kemampuan berpikir kritis pada indikator mempertimbangkan hasil deduksi menunjukkan bahwa baik kelompok atas dan rendah masih kesulitan dalam mengolah informasi dari laporan hasil observasi sehingga berpengaruh kepada kemampuan peserta didik dalam mengambil keputusan akhir. Hal ini disebabkan karena pada saat praktikum tidak semua anggota kelompok ikut berpartisipasi dengan baik dalam menentukan tindakan yang akan dilakukan.

Merujuk pada Tabel 3 persentase pencapaian kemampuan berpikir kritis untuk indikator berinteraksi dengan orang lain diperoleh sebesar 86,81\%. Data ini menunjukkan bahwa peserta didik sangat berkontribusi dalam berinteraksi yang baik 
pada saat melakukan praktikum. Hasil persenatse ini juga menunjukkan bahwa model PBL berbantuan LKPD bermuatan etnosains cocok digunakan untuk mengukur kemampuan berpikir kritis pesera didik. Penelitian yang dilakukan oleh (Aryanti et al., 2017) juga menunjukkan bahwa penggunaan model PBL dapat menngkatkan kemampuan berpikir kritis pada idikator berinteraksi dengan orang ain.

Melalui pembelajaran ni peserta diajak untuk mengeksplorasi pengetahuan dan kemampuan berpikir mereka melalui diskusi dan praktikum. Sehingga peserta didik dapat membangun konsep secara mandiri guna menjawab permasalahan yang terjadi. Menurut (Saheri et al., 2018 Arfianawati et al., 2016) penggunaan model pembelajaran berbasis masalah berpengaruh sebesar 52,63\% untuk meningkatkan keterampilan berpikir kritis peserta didik. Didukung juga oleh penelitian (Arfianawati et al., 2016) bahwa pembelajaran yang terintegrasi etnosains dapat meningkatkan kemampuan berpikir kritis peserta didik. Sejalan juga dengan penelitan yang dilakukan oleh (Baskoro \& Rosdiana, 2018) yang menyatakan bahwa pengunaan lembar kerja yang terintegrasi etnosains dapat memunculkan minat belajar peserta didik. Hal ini dibuktikan dengan hasil angket bahwa peserta didik termotivasi dengan adanya model Problem Based Learning berbantuan LKPD bermuatan etnosains pada materi redoks. Mereka juga menyukai proses pembelajaran yang ditambah dengan adanya kerja kelompok membuat mereka mampu membangun konsep materi secara mandiri.

Kerja kelompok membuat peserta didik dapat mengembangkan ide masingmasing anggota. Hasil ini sesuai dengan penelitian oleh (Darmawati et al., 2017) bahwa pembelajaran $P B L$ membuat peserta didik lebih aktif dalam mengembangkan ide pada saat diskusi. Hal ini menunjukkan peserta didik senang dan tertarik dalam mengikuti pembelajaran kimia dengan model $P B L$ berbantuan LKPD bermuatan etnosains pada materi redoks. Pelaksanaan pembelajaran yang memanfaatkan lingkungan sebagai sumber belajar menjadikan peserta didik lebih mudah memahami materi dan menunjang kemampuan berpikir peserta didik. Model PBL berbantuan LKPD bermuatan etnosains cocok digunakan dalam menjelaskan contoh peristiwa reaksi redoks sehingga peserta didik dapat lebih memahami materi. Penggunaan model ini memberikan pengaruh yang baik dalam mengolah kemampuan berpikir kritis terutama pada indikator berinteraksi dengan orang lain.

Kekurangan dari penggunaan model $P B L$ yang dibantu dengan LKPD bermuatan 
etnosains dalam penelitian ini adalah kurang optimalnya penerapan LKPD bermuatan etnosains untuk menumbuhkan minat belajar peserta didik pada bagian aturan bilangan oksidasi dan konsep reaksi redoks. Ini disebabkan tugas yang diberikan peneliti pada saat pembelajaran model $P B L$ berbantuan LKPD bermuatan etnosains berlangsung, kurang dapat mendukung menyinggung konsep reaksi redoks. Sehingga peserta didik belum mendapatkan pengaruh yang lebih bermakna dan kurang berminat untuk mempelajari reaksi redoks dalam hal mengingat aturan bilangan oksidasi dan konsep reaksi redoks.

\section{SIMPULAN}

Kemampuan berpikir kritis peserta didik termasuk dalam kriteria cukup dengan rata-rata sebesar 62,6. Indikator berinteraksi dengan rang lain dapat berkembang dengan baik, namun indikator menentukan induksi masih dalam kategori rendah. Diperoeh respon positif dari peserta didik terhadap penerapan model PBL berbantuan LKPD bermuatan etnosains. 


\section{DAFTAR PUSTAKA}

Andrianie, D., Sudarmin \& Wardani, S. (2018). Representasi kimia untuk mereduksi miskonsepsi siswa pada materi redoks melalui penerapan model pembelajaran inkuiri terbimbing berbantuan LKS. Chemistry in Education, 7(2), 69-76.

Arfianawati, S., Sudarmin \& Sumarni, W. (2016). Model Pembelajaran Kimia Berbasis Etnosains untuk Meningkatkan Kemampuan Berpikir Kritis Siswa. Jurnal Pengajaran MIPA, 21 (1): 46-51.

Aryanti, F., Surtikanti, H., \& Riandi. (2017). Penerapan problem based learning (PBL) berbantuan teknologi informasi dan komunikasi untuk meningkatkan kemampuan berpikir kritis siswa pada konsep pencemaran lingkungan. BIOSFER J.Bio. \& Pend.Bio, 2(1), 14-20.

Aziz, M. S., Zain, A. N. M., Samsudin, M. A. B., \& Saleh, S. B. (2014). The effects of problem-based learning on self-directed learning skills among physics undergraduates. International Journal of Academic Research in Progressive Education and Development, 3(1), 126-137.

Basheer, A., M. Hugerat, N. Kortam \& A. Hofstein. (2017). The effectiveness of teachers' use of demonstrations for enhancing students' understanding of and attitudes to learning the oxidation-reduction concept. EURASIA Journal of Mathematics Science and Technology Education, 13(3), 555-570.

Baskoro, R. A., \& Rosdiana, L. (2018). Keefektifan LKS guided discovery berbasis etnosains untuk meningkatkan hasil belajar siswa SMP. e-journal-pensa, 06(02), 89-93.

Darmawati, P., Bundu \& Manda, D. (2017). Problem based learning model development of civic education to improve the motivation and learning outcomes. International Journal of Environmental \& Science Education, 12(9), 2049-2061.

Fernanda, A., Haryani, S., Prasetya, A. T., \& Hilm, M. (2019). Analisis kemampuan berpikir kritis siswa kelas xi pada materi larutan penyangga dengan model pembelajaran predict observe explain. Jurnal Inovasi Pendidikan Kimia, 13(1), $2326-2336$.

Imansari, M., Sudarmin., \& Sumarni, W. (2018). Analisis literasi kimia peserta didik melalui pembelajaran inkuiri terbimbing bermuatan etnosains. Jurnal Inovasi Pendidikan Kimia, 12(2), 2201 - 2211.

Kurniastuti, D., Agustina, E. S. W., \& Utami, B. (2016). Peningkatan kemampuan berpikir kritis dan prestasi belajar peserta didik melalui penggunaan model pembelajaran problem solving dilengkapi dengan smart card pada materi kelarutan dan hasil kali kelarutan pada kelas XI IPA di SMA Islam 1 Surakarta tahun ajaran 2016/2017. Jurnal Pendidikan Kimia, 7(1), 95-101. 
Laliyo, L. A. R. (2012). Pengaruh strategi pembelajaran dan gaya kognitif spasial terhadap hasil belajar ikatan kimia siswa kelas XI SMA Negeri di Gorontalo. Jurnal Pendidikan dan Pembelajaran, 19(1), 14-27.

Luzyawati, L. (2017). Analisis kemampuan berpikir kritis siswa SMA materi alat indera melalui model pembelajaran inquiry pictorial riddle. Jurnal Pendidikan Sains \& Matematika, 5(2), 9-21.

Nuryanti, L., S. Zubaidah \& Diantoro, M. 2018. Analisis kemampuan berpikir kritis siswa SMP. Jurnal Pendidikan, 3(2): 155-158.

Saheri, Supardi, K.I., \& Haryani, S. (2017). Pengembangan instrumen penilaian keterampilan berpikir kritis peserta didik SMA melalui model pembelajaran berbasis masalah materi larutan penyangga. Journal of Innovative Science Education, 6(1), 40-48.

Saputra, H., Hidayat, A., \& Munzil. (2016). Profil Kemampuan berpikir kritis siswa SMPN 7 Pasuruan. Proceding Seminar Nasional Pendidikan IPA Pascasarjana UM “Inovasi pembelajaran IPA yang bermakna dan mencerdaskan”, 8 Oktober 2016. Malang: Pascasarjana Universitas Negeri Malang (UM).

Shaer, A. E., \& Gaber, H. (2014). Impact of problem-based learning on students`critical thinking dispositions, knowledge acquisition and retention. Journal of Education and Practice, 5(14), 74-85.

Wijaya, W. S., Feronik, T., \& Fairusi, D. (2018). Penerapan problem based learning berpendekatan SETS terhadap keterampilan berpikir kritis siswa. Jurnal Tadris Kimiya, 3(1), 94-103. 